\title{
INTER SEASON PHYSIOLOGICAL CONTROL OF THE BRAZILIAN BEACH HANDBALL TEAM
}

\author{
CONTROLE FISIOLÓGICO NA INTERTEMPORADA DA SELEÇÃO BRASILEIRA DE HANDEBOL DEPRAIA
}

Original Article

CONTROL FISIOLÓGICO EN LA INTERTEMPORADA DE LA SELECCIÓN BRASILEÑA DEHANDBALL DEPLAYA

ARTIGO ORIGINAL

Artículo Original

\begin{abstract}
Orranette Pereira Padilhas'
(Physical education professional)

Reabias de Andrade Pereira'

(Physical education professional)

Rossana Coeli Seabra Marques²

(Physical education professional)

Douglas Cavalcante Silva'

(Physical education professional)

Keyth Sulamitta de Lima

Guimarães' (Nutritionist)

Diego de Oliveira Costal

(Physical education professional)

Fabiano Ferreira de Lima

(Physical education professional)

Alexandre Sérgio Silva' (Physical

education professional)
\end{abstract}

1. Universidade Federal da Paraíba, João Pessoa, PB, Brazil.

2. Confederação Brasileira de Handebol, João Pessoa, PB, Brazil.

\section{Correspondence:}

Alexandre Sérgio Silva

R. Silvino Lopes, 410/804, Tambaú, João Pessoa, PB, Brazil. 58039-190.

alexandresergiosilva@yahoo.com.br.

\begin{abstract}
Introduction: The Brazilian national women's beach handball team traditionally holds intense pre-competition training with several daily sessions in the weeks before major matches. This can cause excessive physical strain, but physiological monitoring can guide the coaching staff to modulate the training load, preventing this excessive strain. Objective: To monitor the physiological responses of members of the Brazilian national women's beach handball team in a pre-competition training program with loads modulated according to individual physiological response. Methods: Seventeen athletes ( $27.1 \pm 3.8$ years) were assessed before the start of the pre-competition training period (E1), on Day 8 (E2) and Day 18 (E3). Blood samples were taken for subsequent analysis of muscular damage markers (creatine kinase (CK) and lactate dehydrogenase (LDH)). An ECG test was performed to assess cardiac autonomic modulation (CAM), and the Profile of Mood States (POMS) questionnaire was applied to assess mood. The results were reported to the coaching staff, who made training adjustments according to the individual status of each athlete. Results: CK increased significantly from E1 to E2 (131.1 \pm 80.9 vs $212.9 \pm 131.7)$ and remained unchanged (212.9 \pm 185.6$)$ up to E3, while LDH was significantly reduced from E2 to E3 ( $590.7 \pm 120.2$ vs $457.8 \pm 86.6)$, finishing the pre-competition training program with values similar to E1 $(512.7 \pm 190.6)$. The only change noted was the subjective sensation of fatigue from the POMS questionnaire that was significantly higher in E2 (4.82 \pm 4.05$)$ and E3 $(5.5 \pm 4.8)$ compared to E1 $(2.06 \pm 2.61)$, but no changes in total mood disturbance were detected in this instrument. Conclusion: With the modulation of training loads based on results of physiological tests, the members of the Brazilian national women's beach handball team responded in a physiologically adequate manner, even when faced with a sudden increase in training load for 18 consecutive days. Level of evidence III; Diagnostic study-Investigation of a diagnostic test.
\end{abstract}

Keywords: Physical exercise; Monitoring; Physiology; Athletes.

\section{RESUMO}

Introdução: A seleção brasileira de handebol de praia tradicionalmente realiza uma intertemporada de treinamentos intensos com várias sessões diárias nas semanas anteriores às principais competições. Isso pode gerar um desgaste excessivo, mas a monitoração fisiológica pode orientar a comissão técnica para modular as cargas de treino, evitando esse desgaste. Objetivo: Monitorar as respostas fisiológicas de atletas da seleção brasileira feminina de handebol de praia em uma intertemporada de treinamento com cargas moduladas em função das respostas fisiológicas. Métodos: Dezessete atletas (27,1 $\pm 3,8$ anos) foram avaliadas antes do início da intertemporada (E1), no $8^{\circ}$ dia (E2) e no 180 dia (E3). Foram coletadas amostras de sangue para posterior análise de marcadores de desgaste muscular (creatina quinase [CK] elactato desidrogenase [LDH]), um registro eletrocardiográfico foi feito para avaliação da modulação autonômica cardíaca (MAC) e aplicou-se o questionário Profile of Mood States (POMS) para avaliação do estado de humor. Os resultados eram informados à comissão técnica, que realizava ajustes nos treinos em função do estado individual de cada atleta. Resultados: A CK aumentou significativamente de E1 para E2 $(131,1 \pm 80,9$ vs. 212,9 $\pm 131,7)$ e ficou inalterada $(212,9 \pm 185,6)$ atéE3, enquanto o LDH foi significativamente reduzido de E2 para E3 $(590,7 \pm 120,2 \mathrm{vs}$. 457,8 $\pm 86,6)$, terminando a intertemporada com valores similares a E1 $(512,7 \pm 190,6)$. A única alteração notada foi a sensação subjetiva de fadiga do questionário POMS, que se apresentou significativamente elevada no E2 $(4,82 \pm 4,05)$ e no $E 3(5,5 \pm 4,8)$ em relação ao E1 $(2,06 \pm$ 2,61), mas sem alteração da perturbação total de humor detectada neste instrumento. Conclusão: Com a modulação das cargas de treinamento em função de resultados de testes fisiológicos, as atletas da seleção brasileira de handebol de praia respondem de forma fisiologicamente adequada, mesmo perante brusco aumento das cargas de treinamento por 18 dias consecutivos. Nível de evidência Ill; Estudo diagnóstico - Investigação de um exame para diagnóstico.

Descritores: Treinamento físico; Monitoração; Fisiologia; Atletas.

\section{RESUMEN}

Introducción: La selección brasileña de handball de playa tradicionalmente realiza una intertemporada de entrenamientos intensos con varias sesiones diarias en las semanas anteriores a las principales competiciones. Eso puede generar un desgaste excesivo, pero la monitorización fisiológica puede orientar a la comisión técnica para modular las cargas de entrenamiento, evitando ese desgaste. Objetivo: Monitorizar las respuestas fisiológicas de atletas de la selección brasileña femenina de handball de playa en una intertemporada de entrenamiento con cargas moduladas en función de las respuestas fisiológicas. Métodos: Diecisiete atletas (27,1 $\pm 3,8$ años) fueron evaluadas 
antes del inicio de la intertemporada (E1), en el $8^{\circ}$ día (E2) y en el $18^{\circ}$ día (E3). Fueron colectadas muestras de sangre para posterior análisis de marcadores de desgaste muscular (creatina quinasa [CK] y lactato deshidrogenasa [LDH]), fue hecho un registro electrocardiográfico para evaluación de la modulación autonómica cardíaca (MAC) y se aplicó el cuestionario Profile of Mood States (POMS) para evaluación del estado de humor. Los resultados eran informados a la comisión técnica, que realizaba ajustes en los entrenamientos en función del estado individual de cada atleta. Resultados: La CK aumentó significativamente de E1 para E2 $(131,1 \pm 80,9$ vs. 212,9 $\pm 131,7)$ y quedó inalterada $(212,9 \pm 185,6)$ hasta E3, mientras que el LDH fue significativamente reducido de E2 para E3 $(590,7 \pm 120,2 \mathrm{vs} .457,8$ $\pm 86,6)$, terminando la intertemporada con valores similares a E1 (512,7 $\pm 190,6)$. La única alteración notada fue la sensación subjetiva de fatiga del cuestionario POMS, que se presentó significativamente elevada en E2 $(4,82 \pm 4,05)$ y en E3 $(5,5 \pm 4,8)$ con relación a E1 $(2,06 \pm 2,61)$, pero sin alteración de la perturbación total de humor detectada en este instrumento. Conclusión: Con la modulación de las cargas de entrenamiento en función de resultados de tests fisiológicos, las atletas de la selección brasileña de handball de playa responden de forma fisiológicamente adecuada, aún ante brusco aumento de las cargas de entrenamiento por 18 días consecutivos. Nivel de evidencia III; Estudio diagnóstico - Investigación de un examen para diagnóstico.

Descriptores: Ejercicio físico; Monitoreo; Fisiología; Atletas.

\section{INTRODUCTION}

Beach handball is a new sport in world cenary and it is in a way of beginning an Olympic sport in 2016. This modality emerged in 1992 in Italy and fastly spread for the world coming in Brazil at 90 years'. As many differences than indoor handball ${ }^{1}$, beach handball trainings and competitions are performed on the beach sand floor, which make activities more wearing. Furthermore, games are played with just three line-mans and many substitutions, so that the movement of the athletes is intense on two sets of 10 minutes of the each game ${ }^{2}$.

Female Brazilian beach handball team, is nowadays three times champion of the world $(2006,2012,2014)$, and the first placed in world ranking (International Handball Federation). Brazilian beach handball committee organizes the schedule to that the athletes are summoned, in the last weeks before more important competitions of the season, to do a pre-competitive period of intensive training, usually with two to four weeks and ending at the last week before the event.

Despite of technical and tactical benefits of this pre-competitive period, the physical wear promoted by intensive training of this modality is a real possibility, so need to be avoid because risk of decrease of athlete's performance, specially considering that the pre-competitive period occurs in the last microcycle before the mains competitions of the season.

On this perspective, was conducted an action-research study, which the researchers independently of Brazilian Handball Confederation (Confederação Brasileira de Handebol) performed a physiological monitoring of 19 days in pre-competitive period as mean of to provide parameter to the coaches and athletes, so that they could modulate training loads in function of the outcomes.

Then, the aim of this study was to offer a description of how Brazilian beach handball athletes respond to a pre-competitive training period physiologically monitored by training loads outcomes, by muscle damage markers, cardiac autonomic nervous activity and mood state, being the training loads influenced by this physiological results.

\section{MATERIAL AND METHODS}

Was developed an action-research, which partial results of the study was communicated to technical committee that had liberty to change training loads in function of the information of the tests results.

\section{Sample}

Study was performed with seventeen female athletes of Brazilian national beach handball team $(27,1 \pm 3,8$ years). The participants were informed about the procedures involved and asked to sign the informed consent form according to resolution 466/12 of the Brazilian National Health Council that follow the Helsinki Declaration. This study was previously approved by the Research Ethics Committee of University Hospital Lauro Wanderley from Federal University of Paraíba, under protocol number 357.246/13.

\section{Study design}

The athletes participated to a pre-competitive training period of 18 days that occurred in last three weeks before Beach Handball World Championship (2014). Immediately before of trainings, in 8th and 18th day, blood collection was performed to posterior analysis of muscle damage (creatine kinase and lactate dehydrogenase), one electrocardiography register was performed to evaluate the heart rate variability (HRV) and a psychometric test was performed to evaluate the profile of mood state (POMS). Two days after each evaluation, the results were communicated to technical committee, so that they could change training loads in function of obtained results.

\section{Preparation to evaluations}

Twenty-four hour after the athletes arrive in city of pre-competitive period and before first training session, was performed the first evaluation (E1). The next evaluations were performed on $8^{\text {th }}$ day (E2) and $18^{\text {th }}$ day (E3) on Monday morning and Friday morning before of first training of days, respectively, preceded by 36 hours of rest.

\section{Blood collection and biochemical analysis}

Were collected eight millimeters of blood of the antecubital venom by a trained nurse. The samples were transfer to tubes and centrifuged at 3000 rpm for 15 minutes (Centribio ${ }^{\circledR} 80-2 B$ ). The supernatant was transferred to microtubes and cooled on $-20^{\circ} \mathrm{C}$ until the analyzes. Enzymes CK and LDH were analyze, using specific commercial kits of Labtest (Lagoa Santa, Brazil) in an automatic analyzer Labtest (Labmax 240 premium).

\section{Heart Rate Variability (HRV)}

This measure has been widely used in sportive scope to monitoring physiological training responses of athletes ${ }^{3}$. Was performed a register of heart rate variability, using a heart rate monitor Polar RS800CX (Polar Electro Oy, Kempele, Finland). This portable device was validated by rest electrocardiographic register and during the exercise ${ }^{4,5}$. Register was performed for three minutes with athletes sitting, after 10 minutes of rest. Data were transferred to computer by polar Pro trainer 5 software and analyzed on Kubios HRV software (version 2.2, Biosignal Analysis and Medical Image Group, Finland). 


\section{POMS}

Was applied a psychometric evaluation questionnaire (Profile of Mood States). It is an adapted version of original scale that was initially translated to Portuguese by Viana, Almeida e Santos in $2001^{6}$ and used in many works of psychological evaluation. This tool is a self-supporting form which athletes report, in 0 to 4 scale, how they were felling in the last seven days in relation to tension, depression, hostility, vigor, fatigue and confusion. The application was done in a quiet room and aided by researcher to clarify possible doubts and to warrant that athletes has not disturbed or has saw answers of others.

\section{Communication of partial results}

Partial results of the evaluations were communicated to technical committee 48 hours after each data collection. Thus, the coaches performed modifications in relation of foreseen training on individual way, removing some session or decreasing training loads to regenerative trainings in one or more daily session, but never leaving the athletes without at least one intensive training a day.

\section{Training Loads}

Pre-competitive period had 18 days of duration. Until the 8th day the athletes trained three times a day during week (07:00 - 09:00 am, 11:30 am - 13:30pm and 16:00 - 18:00 pm) and one session at Saturdays (08:00 - 10:00 am). Although prevised rest to Sundays, on second Sunday there was a game simulation. It was prevised two sessions of neuromuscular training on morning during week through resistance training. Table 1 show a synthesis of activities performed during this pre-competitive period.

From of 10th day the technical committee promote reduction of training loads, taking in consideration results of physiological tests. This reduction was performed eliminating neuromuscular trainings, adjusting individually the kind of training and improving strategies of recovery of some athletes by cryotherapy and increase the sleep time.

\section{Statistical analysis}

Initially data were tested which normality and variability using Shapiro Wilk and Levene tests, respectively. After that, was applied ANOVA to repeated measures with Turkey post hoc. Was adopted significance level $p<0.05$. For this was used Graphpad Instat 3.0 software (GraphPAd Instat, San Diego, CA, USA).

\section{RESULTS}

CK values increased significantly from beginning to middle of pre-competitive period, but keep on similar values until the end, without differences to beginning or anterior moment. On the other hand, LDH value decreasing significantly from middle to end of pre-competitive period, ending this period with minor values than beginning (Table 2).

Table 3 show behavior of cardiac autonomic nervous activity. Data of RMSSD and PNN50 indicating a discreet fluctuation of parasympathetic, with reduction of this variable on final evaluation of pre-competitive period, but without statistical differences between previous evaluations. This connotation is confirmed by frequency domain (HF) and autonomic

Table 1. Summary of daily training during an inter-season of the athletes of the Brazilian beach handball team.

\begin{tabular}{l|c|c|c|c}
\hline & $\begin{array}{c}\text { Monday, Wednesday } \\
\text { and Friday }\end{array}$ & $\begin{array}{c}\text { Tuesday and } \\
\text { Thursday }\end{array}$ & Saturday & Sunday \\
\hline 1st Training & $\begin{array}{c}\text { Indoor Physical } \\
\text { Training }\end{array}$ & $\begin{array}{c}\text { Neuromuscular } \\
\text { Training }\end{array}$ & $\begin{array}{c}\text { Technical/ } \\
\text { Tactical }\end{array}$ & $\begin{array}{c}\text { Rest or Match } \\
\text { simulation }\end{array}$ \\
\hline 2st Training & Technical/Tactical & Technical/Tactical & & \\
\hline 3st Training & Match simulation & Match simulation & & \\
\hline
\end{tabular}

balance (LF/HF), that showed stability on results during this study. On the same mode, LF indicated no one significant alterations on cardiac sympathetic activity during the pre-competitive period.

There were no alterations on total mood disturbance during the pre-competitive period. However, was observed an increase of fatigue scale at the middle and end, compared to beginning of pre-competitive period (Table 4).

Table 2. Biochemical markers of muscular damage of athletes of the Brazilian beach handball team during an inter-season period.

\begin{tabular}{c|c|c|c}
\hline & E1 & E2 & E3 \\
\hline $\mathrm{CK}(\mathrm{U} / \mathrm{L})$ & $131,1 \pm 80,9$ & $212,9 \pm 131,7^{\#}$ & $212,9 \pm 185,6$ \\
\hline $\mathrm{LDH}(\mathrm{mg} / \mathrm{dL})$ & $512,7 \pm 190,6$ & $590,7 \pm 120,2$ & $457,8 \pm 86,6^{*}$ \\
\hline Data are mean \pm standard deviation. CK: creatine kinase, $\mathrm{LDH}$ : lactate dehydrogenase. \#Statistical difference
\end{tabular}
in the Kruskal-Wallis test $\mathrm{p}<0.05$. ${ }^{*}$ Statistical difference in the ANOVA one-way test $\mathrm{P}<0.05$.

Table 3. Heart Rate Variability of athletes of the Brazilian National Beach Handball team during an interseason period.

\begin{tabular}{c|c|c|c|c}
\hline & E1 & E2 & E3 & P value \\
\hline Mean RR & $918 \pm 167$ & $876 \pm 188$ & $822 \pm 134$ & 0.29 \\
\hline SDNN & $60,7 \pm 16,5$ & $65,7 \pm 30,9$ & $87,1 \pm 54,1$ & 0.34 \\
\hline RMSSD & $50,4 \pm 20,6$ & $55,4 \pm 35,4$ & $42,5 \pm 19,5$ & 0.37 \\
\hline PNN50 & $29,5 \pm 18,4$ & $27,1 \pm 26,5$ & $19,7 \pm 18,1$ & 0.43 \\
\hline LF & $1111 \pm 696$ & $1556 \pm 1871$ & $1231 \pm 859$ & 0.87 \\
\hline HF & $1003 \pm 637$ & $1114 \pm 1197$ & $659 \pm 653$ & 0.39 \\
\hline LF/HF & $1,4 \pm 1,1$ & $2,1 \pm 1,5$ & $2,6 \pm 1,4$ & 0.14 \\
\hline
\end{tabular}

Data are mean \pm standard deviation. Mean RR: mean R-R interval, SDNN - standard deviation of the mean of the RR intervals: RMSSD: root mean square of successive differences; PNN50: percentage of RR intervals with difference greater tha 50 milliseconds; LF: Iow frequency; HF: high frequency. Test KuskalWalis, one-way or Kruskal Wallis Test, depending on the variable.

Table 4. Psychological parameters of athletes of the Brazilian National beach handball team during an interseason period.

\begin{tabular}{c|c|c|c}
\hline & E1 & E2 & E3 \\
\hline TMD & $92,06 \pm 12,03$ & $91,82 \pm 8,99$ & $97,5 \pm 14,3$ \\
\hline Tension & $4,82 \pm 3,57$ & $3,88 \pm 2,34$ & $4,9 \pm 2,8$ \\
\hline Depression & $1,41 \pm 2,21$ & $1,06 \pm 1,75$ & $1,6 \pm 3,0$ \\
\hline Hostilities & $2,53 \pm 2,37$ & $1,41+1,46$ & $2,4 \pm 2,9$ \\
\hline Vigor & $16,82 \pm 4,60$ & $17,65 \pm 3,64$ & $16,0 \pm 5,2$ \\
\hline Fatigue & $2,06 \pm 2,61$ & $4,82 \pm 4,05^{*}$ & $5,5 \pm 4,8^{*}$ \\
\hline Confusion & $-1,94 \pm 2,68$ & $-1,71 \pm 1,86$ & $-1,0 \pm 2,2$ \\
\hline TDS & $0,88 \pm 1,93$ & $0,41 \pm 1,23$ & $1,5 \pm 3,0$ \\
\hline
\end{tabular}

Data are mean \pm standard deviation. TMD $=$ Total Mood Disturbance. TDS: Training Distress Scale * indicates $p=0.0163$.

\section{DISCUSSION}

This study showed that athletes of elite beach handball respond to 18 days of pre-competitive intensive training and multiple daily sessions with increase of muscle damage, but followed by restauration at the end of this training. This discreet fluctuation on muscle damage was accompanied by increase in just one (fatigue) of dimensions of mood state test. This data indicating a physiological response without abnormal perturbations during this training.

The life routine of athletes of the Brazilian Beach Handball team have had abrupt changing near to competition. Before this pre-competitive period the athletes just have one training a day and during the three weeks they have three sessions a day. This procedure is standard to this team, always before main competitions.

Abrupt changes in training routine are accepted with one factor causers of overtraining ${ }^{7-9}$. Usually is expected a training routine with multiple daily sessions in pre-season in many sports, to stimulate adaptative mechanisms that improve the performance. However, this pre-season is applied far way of competitions, while it is opposite in the beach handball, once that a pre-competitive period with increase of training 
loads is performed near the main competitions of this sport. In fact, literature recommends the opposite before competitions, ie a reduction of training loads in pre-competitive period ${ }^{10-12}$.

Despite of this apparent contradictions between theorical presupposes and procedures adopted by this national team, data of this study showed that the athletes responded physiologically to this pre-competitive trainings. Muscle damage occurred after seven days of trainings no longer appeared in the end of pre-competitive period, take considering CK values. Furthermore, LDH values, another muscle damage marker presented minor values in the last day of this period, being statically minor than middle and descriptively minor than beginning.

According Smith theory ${ }^{13}$, overreaching is characterized by local inflammatory process (muscle), which evolves to systemic proportion. Such as result, occurred various neuro-immune-endocrines, which increase cardiac sympathetic or parasympathetic nervous activity and causes comportamental disturbances. While this, psychometric test adopted revealed that the athletes do not presented any mood alteration. Take this together, data indicate that the athletes did not had systemic perturbations of overreaching and overtraining.

On the other side, precisely fatigue sensation dimension of psychometric was the only dimension that increase during the inter-season. This result can be understood with an obvious response, given of high intensity and volume of training load of this period, but the others data of this study showed that did not occur repercussion in the others dimensions or physiologic variables.

Absence of physiological wear, even with abrupt increase in training loads, can be explained by fact of the athletes passed for this process, after many training months, so that they presented enough time of training to support this training demand, which does not occur when this training protocol is applied in athletes in beginning of season. In fact, previous data show that athletes with more time of training support better the training loads ${ }^{14}$

It is important highlight that monitoring presented to coaches, represented a important element in this inter-season, because it induced technical committee to decrease training loads in function of physiological individual situation. In fact, it was consolidated by reduction in training load from $10^{\circ}$ day of inter-season. Moreover, athletes that presented individual values more altered received special attention to bigger sleep time, to reduction of training loads and use of physiotherapy tools (e.g. cryotherapy).

Although we have showed absence of systemic imbalance indicative of overreaching or overtraining, should be that this study had limitations on variables included. While muscle damage markers, heart rate variability and mood state were evaluated, it is known that other tools are indicators of overtraining ${ }^{13,15}$ such as hormonal alterations, oxidative stress, systemic inflammation ${ }^{16-19}$. Therefore, markers to theses variables are proposed to future studies.

\section{CONCLUSION}

Data of this study showed that athletes from the Brazilian national beach handball team respond physiologically to the training loads of an inter-season close to a competition when the coaching staff modulates the training loads individually or collectively according to the results of physiological tests, even in abrupt increase on training loads for 18 consecutive days.

All authors declare no potential conflict of interest related to this article.

AUTHORS' CONTRIBUTIONS: Each author made significant individual contributions to this manuscript. OPP (0000-0001-6747-3337)*: data collection, biochemical analyses, statistics; RAP (0000-0001-7171-4551)*: data collection, preparation of the manuscript; RCSM (0000-0002-9523-7590)*: conception of the research; DCS (0000-0002-4005-6477)* data analysis and drafting of the manuscript; DOC (0000-0003-1200-9400)*: data collection and analyses; FFL, (0000-0003-1841-509)*: data collection and analyses; ASS (0000-0003-3576-9023): conception of the idea of the work, data analysis and critical review. ${ }^{*} \mathrm{ORCID}$ (Open Researcher and Contributor ID).

\section{REFERENCES}

1. Oliveira VC, Machado DA, Nunes JRA, Navarro AC. Análise Do VO2MÁX de atletas convocados para a Seleção Brasileira de handebol de areia. Rev Bras Prescrição e Fisiol do Exerc. 2009:3(17):500-4.

2. Silva AS, Marques RCS, Lago SA, Santos DAG, Lacerda LM, Silva DC, et al. Physiological and nutritional profile of elite female beach handball players from Brazil. J Sports Med Phys Fitness. 2016;56(5):503-9.

3. Vanderlei LCM, Pastre CM, Hoshi RA, Carvalho TD, Godoy MF. Noções básicas de variabilidade da frequência cardíaca e sua aplicabilidade clínica. Rev Bras Cir Cardiovasc. 2009;24(2):205-17.

4. Nunan D, Donovan G, Jakovljevic DG, Hodges LD, Sandercock GR, Brodie DA. Validity and reliability of short-term heart-rate variability from the Polar S810. Med Sci Sports Exerc. 2009;41(1):243-50.

5. Porto LGG, Junqueira LF. Comparison of time-domain short-term heart interval variability analysis using a wristworn heart rate monitor and the conventional electrocardiogram. Pacing Clin Electrophysiol. 2009;32(1):43-51.

6. Viana MF, Almeida PI, Santos RC. Adaptação Portuguesa Da Versão Reduzida Do Perfil de Estados de Humor: POMS. Aná Psicológica. 2001;1(19):77-92.

7. Armstrong LE, VanHeest. The Unknown Mechanism of the Overtraining Syndrome: Clues from Depression and Psychoneuroimmunology. Sports Med. 2002;32(3):185-209.

8. Meeusen R, Duclos M, Gleeson M, Rietjens G, Steinacker J, Urhausen A. Prevention, Diagnosis and Treatment of the Overtraining Syndrome. Eur J Sport Sci. 2006;6(1):1-14

9. Coutts AJ, Slattery KM, Wallace LK. Practical Tests for Monitoring Performance, Fatigue and Recovery in Triathletes. J Sci Med Sport. 2007;10(6):372-81

10. Bosquet L, Jonathan M, Denis A, Iñigo M. Effects of Tapering on Performance: A Meta-Analysis. Med Sci Sports Exerc. 2007;39(8):1358-65.
11. Brännström A, Anton R, Ji-guo Y. Effects and Mechanisms of Tapering in Maximizing Muscular Power. Sport and Art. 2013;1(1):18-23.

12. Mujika I, Padilla S, Pyne D, Busso T. Physiological Changes Associated with the Pre-Event Taper in Athletes, Sports Med. 2004;34(13):891-927.

13. Smith UL. Cytokine Hypothesis of Overtraining: A Physiological Adaptation to Excessive Stress? Med Sci Sports Exerc. 2000;32(2):317-31

14. Wilmore JH, Costill DL. Fisiologia do esporte e do exercício. São Paulo: Manole; 2001

15. Rogero MM, Mendes RR, Tirapegui J. Aspectos neuroendócrinos e nutricionais em atletas com overtraining Arq Bras Endocrinol Metab. 2005:49(3):359-68.

16. Smith LL. Overtraining, Excessive Exercise, and Altered Immunity: Is This a T Helper-1 versus T Helper-2 Lymphocyte Response? Sports Med. 2003;33(5):347-64.

17. Margonis K, Fatouros IG, Jamurtas AZ, Nikolaidis MG, Douroudos I, Chatzinikolaou A, et al. Oxidative Stress Biomarkers Responses to Physical Overtraining: Implications for Diagnosis. Free Radic Biol Med. 2007:43(6):901-10.

18. Tanskanen M, Atalay M, Uusitalo, ALT. Altered Oxidative Stress in Overtrained Athletes. J Sports Sci. 2010;28(3):309-17.

19. Meeusen R, Duclos M, Foster C, Fry A, Gleeson M, Nieman D, et al. Prevention, Diagnosis, and Treatment of the Overtraining Syndrome: Joint Consensus Statement of the European College of Sport Science and the American College of Sports Medicine. Med Sci Sports Exerc. 2013;45(1):186-205 